\title{
Fluorocarbon Treatment for Purification of Antigens of Ehrlich Ascites Tumor Cells
}

\author{
By \\ Mitsuru Konn* \\ Department of Surgery, Hirosaki University School of \\ Medicine, Hirosaki; Director: Prof. K. O h-U ti \\ Department of Bacteriology, Tohoku University School \\ of Medicine, Sendai; Director: Prof. N. I sh id a \\ (Received for publication, May 4, 1964)
}

\begin{abstract}
In an attempt to examine tumor specific antigens, the crude suspensions of Ehrlich ascites tumor cells and the mouse muscle homogenates were treated by fluorocarbon. Antisera against the fluorocarbon treated antigens were prepared in rabbits. The antisera were tested for the presence of antibodies against the homologous and heterologous antigens by complement fixation test. The anti-tumor serum contained antibody against the homologous antigen, but no detectable amount of antibody against the muscle antigen. The antimuscle serum, conversely, possessed an antibody against the muscle antigen, but showed no antibody against the tumor antigen. By means of the complement method of immunofluorescence, Ehrlich tumor cells were specifically stained with the anti-tumor serum. The staining titer, as expressed by its final effective dilution, was comparable to those demonstrated in the in vitro complement fixation test. Furthermore, it was found by immunofluorescence that the anti-tumor serum stained the cells of ascites of sarcoma 180 and those of leukemic ascites tumor SN 36 in mice, but not the peritoneal non-tumor cells obtained from normal mouse.
\end{abstract}

The fluorocarbon treatment has been applied for the purification of complement fixing (CF) antigens of many viruses ${ }^{1-6)}$. Taylor et al. ${ }^{7)}$ reported the effect of fluorocarbon treatment on extraction of certain neoplastic tissues. They found that host tissue CF antigens could be removed from crude tumor suspensions, leaving tumor specific $\mathrm{CF}$ antigens. Those purified antigens were evident as sedimentable particles by ultracentrifugation, suggesting that the antigens were virus-like particles or microsomes.

今 态

* This work was submitted as a part of Doctor of Medical Science thesis to the Graduate Division, Hirosaki University School of Medicine. 
It is interesting to know whether the specific antigens of Ehrlich ascites tumor cells are separatable from host tissue antigens by means of fluorocarbon treatment. The cells were considered to be suitable materials for the immunological studies of transplantable tumors, because a large amount of cells per mouse could be easily obtained without being contaminated with normal host cells.

The present paper concerns with the effect of fluorocarbon treatment in purification of tumor specific antigen of Ehrlich ascites tumor cells, as studies by both CF test and immunofluorescence. The results showed that rabbit antiserum obtained at early stage during immunization with the fluorocarbon treated antigen of tumor cells possessed a high titer of antibody against the homologous tumor antigen, but reacted only partially with host tissue antigens.

\section{MATERIALS AND METHODS}

Ehrlich ascites tumor cells. This tumor has been maintained in the Department of Bacteriology, Tohoku University School of Medicine by serial transferes in the $d d$ strain of white mice. Approximately $2 \times 10^{6}$ cells were inoculated intraperitoneally into mice of $15-20 \mathrm{gm}$, and the tumor cells were collected 7-8 days later. The harvested cells were washed 3 to 5 times with $\mathrm{M} / 100$ phosphate buffered saline (PBS) of $\mathrm{pH} \mathrm{7.2,} \mathrm{until} \mathrm{the} \mathrm{preparation} \mathrm{became} \mathrm{free} \mathrm{from} \mathrm{red} \mathrm{blood} \mathrm{cells.} \mathrm{The}$ cells were packed by centrifugation at $2,000 \mathrm{rpm}$ for 10 minutes, and stored at $-20^{\circ} \mathrm{C}$ until use.

Preparation of crude antigens of the cells. The packed cells were suspended in an equal volume of cold distilled water and homogenized in a Waring blendor. The homogenate was centrifuged at 2,000 rpm for 10 minutes and the supernatant fluid was carefully removed. To the aqueous solution, 3 volumes of distilled water was added. Thus resultant solution contained 11 to $15 \mathrm{mg} / \mathrm{ml}$ of protein and was designated as the crude antigens of tumor.

Fluorocarbon treatment. A fluorocarbon, Daiflon $\mathrm{S}_{3}\left(\mathrm{CCl}_{2} \mathrm{~F}-\mathrm{CClF}_{2}\right)$ was used. A one-half volume of the fluorocarbon (FC) was added to the crude antigen, homogenization of one minute duration was repeated in the Waring blendor 4 times, with each time following by one minute pause, and the homogenate was centrifuged at $2,000 \mathrm{rpm}$ for 10 minutes. The aqueous layer was removed and treated with FC two more times in the same manner. Thus obtained aqueous solution contained 4.2 to $3.8 \mathrm{mg} / \mathrm{ml}$ of protein and was designated as the $\mathrm{FC}$ treated antigen.

Preparation of muscle antigens of mouse. The host tissue antigens were prepared from the mouse muscle. The muscles were removed from the extremities and torso, and homogenized by the same procedure in the tumor cells. The homogenate was treated with $\mathrm{FC}$ twice. The antigen contained $4 \mathrm{mg} / \mathrm{ml}$ of protein. 
Rabbit immunization. The adult rabbits weighing from 2.5 to $3.5 \mathrm{~kg}$ were used for immunization with various antigens. Appropriate dilutions of antigens in PBS were injected intravenously throughout the experiments. Bleeding from the veins of rabbits was carried out 5 days after the last injection, and sera were heated at $60^{\circ} \mathrm{C}$ for 20 minutes and stored at $-20^{\circ} \mathrm{C}$. The details of schedule of immunizations are described in the section of results.

$C F$ test. The tests were done according to the procedure presented by Hummeler ${ }^{8}$. Titer of either antigen or antibody was examined by the box titration procedure. Test sera inactivated by heating were absorbed with sheep red blood cells before the titration. For CF test, the FC treated tumor antigen and the FC treated muscle antigen were used. Concentration of protein in the each antigen was adjusted to $4 \mathrm{mg} / \mathrm{ml}$ before the titration. The antigens in this concentration did not show anticomplementary effect.

Preparation of cell-smears for immunofluorescence. The freshly harvested cells were washed throughly with PBS, smeared on slide glasses and dried at room temperature for 30 minutes. They were then fixed with acetone for 10 minutes at room temperature.

Immunofluorescent procedure. Throughout the experiments, the complement method 9) of immunofluorescent procedures were adopted. The fixed cell smears were overlayed with a mixture of appropriately diluted antiserum and an equal volume of guinea pig complement 1:10 dilution, and incubated at $37^{\circ} \mathrm{C}$ for 30 minutes and then washed with PBS. After PBS was drained off, the slides were overlayed with the anticomplement antibody conjugated with fluorescein isothiocyanate at $37^{\circ} \mathrm{C}$ for 30 minutes. The ratio of fluorescein to protein in the fluorescent antibody used here was $5 \times 10^{-3}$, and the concentration of $0.5 \mathrm{mg}$ protein/ $\mathrm{ml}$ was used for staining. After washing they were mounted on glass slides with a semi-parmanent mounting medium. The stained preparations were examined and photographed with Olympas F Tr-type microscope using Tiyoda H 250 mercury lamp. For photography, Fuji Neopan SSS (ASA 200) was used.

\section{RESULTS}

Four rabbits were immunized with the FC treated tumor antigen, one with the crude tumor antigen and one with the $\mathrm{FC}$ treated muscle antigen. Immunizations were carried out under the following schedule unless otherwise stated. The animals received three intravenous injections per week for 2 weeks and were bled 5 days after the last injection. Antigens injected each time weighed $4 \mathrm{mg}$ as protein. The antieera prepared are shown in Table I. First, the following antisera were tested for titer of antibody against either FC treated tumor antigen or FC treated muscle antigen in the CF test: No. 14-1 serum prepared by immunization with the crude tumor antigen; No. 11-1, No. 12-1 and No. 13-1 serum by the FC treated tumor antigen; No. 2-1 serum by the FC treated muscle antigen. 
Table I. Rabbits Antisera to the Tumor Cell Antigen and to the Muscle Antigen

\begin{tabular}{|c|c|c|c|}
\hline Serum no. & $\begin{array}{l}\text { Individual } \\
\text { rabbit no. }\end{array}$ & $\begin{array}{l}\text { Antigen for } \\
\text { immunization }\end{array}$ & $\begin{array}{l}\text { Total amount of } \\
\text { protein in the } \\
\text { antigen injected } \\
(\mathrm{mg})\end{array}$ \\
\hline $2-1$ & 2 & $\begin{array}{l}\text { Fluorocarbon } \\
\text { treated muscle } \\
\text { antigen }\end{array}$ & 24 \\
\hline $7-1^{a}$ & 7 & $\begin{array}{l}\text { Fluorocarbon } \\
\text { treated tumor } \\
\text { cell antigen }\end{array}$ & 32 \\
\hline $7-2^{b}$ & 7 & $"$ & 46 \\
\hline $7-3^{c}$ & 7 & $"$ & 66 \\
\hline $11-1$ & 11 & " & 24 \\
\hline $12-1$ & 12 & $"$ & 24 \\
\hline $13-1$ & 13 & " & 24 \\
\hline $14-1$ & 14 & $\begin{array}{l}\text { Crude tumor } \\
\text { antigen }\end{array}$ & 24 \\
\hline
\end{tabular}

a. The no. 7 rabbit was injected with $12 \mathrm{mg}$ of protein of the antigen at the first shot, otherwise same as the routine schedule.

b. The no. 7 rabbit was boostered with $14 \mathrm{mg}$ protein of the antigen 4 weeks after the last injection in the routine immunization.

c. The no. 7 rabbit was boostered again with $20 \mathrm{mg}$ protein of the antigen 2 weeks after last booster.

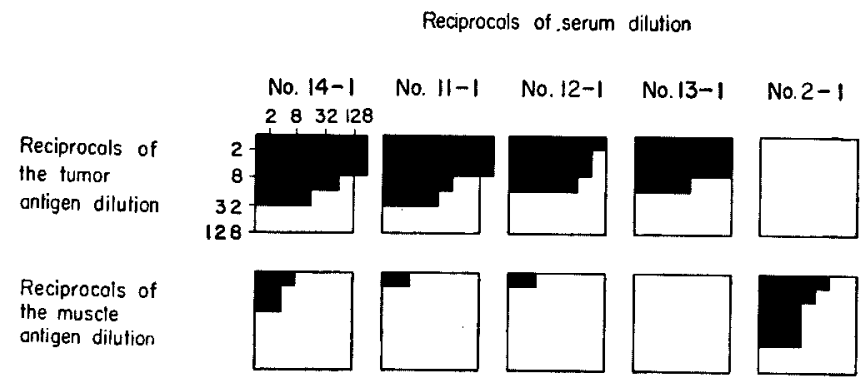

Fig. 1

Results are shown in Fig. 1. No. 14-1 serum showed a high titer of the antibody against the tumor antigen, and to a lesser extent the muscle antigen. In the three antisera, No. 11-1, No. 12-1 and No. 13-1, high titer of antibody against the tumor antigen was revealed, while the antibody against the muscle antigen was undetectable (No. 13-1) or extremely low. The No. 2-1 serum contained a high titer of antibody against the homologous antigen but no antibody against the tumor antigen. The results suggested that the FC treatment was highly effective for removing a common antigen to muscle from the crude tumor antigen. 
Reciprocals of serum dilution

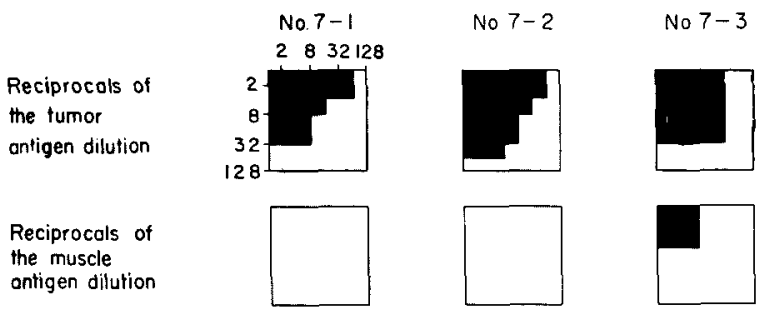

Fig. 2

However, it was also true that the $\mathrm{FC}$ treated tumor antigen preparation still contained certain amount of the common antigen. The existence of the common antigen in the $\mathrm{FC}$ treated tumor antigen could be demonstrated more clearly in the sera obtained by the booster injections. As shown in Table I and Fig. 2, in No. 7-1 and No. 7-2 sera which were obtained after the routine immunization and the first booster respectively, the high titer of antibody against the tumor antigen were shown, while the antibody against the muscle antigen was not detectable. However, the serum No. 7-3 obtained after the second booster contained antibodies against both the tumor antigen and the muscle antigen, although the titer was lower to the muscle antigen than to the tumor antigen.

It was reported by Hinuma and his coworkers $\left.{ }^{9}, 10\right)$ that virus antigens conld be stained with antiviral serum which contained CF antibody, by means of a complement method of immunofluorescence. They also demonstrated that staining titer of an antiserum determined by this immunofluorescent procedure was mostly comparable to the titer of in vitro $\mathrm{CF}$ test. Experiments were carried out to know whether their observations are valid for cellular antigen-antibody system in the present studies. The immune sera against FC treated tumor antigen, No. 11-1, No. 12-1 and No. 13-1, were tested for the stainability and then staining titers were determined, using of the fixed smears of the Ehrlich ascites tumor cells, by means of the complement method of immunofluorescence. A typical feature of the tumor cells stained by the complement method using of the anti-tumor serum are shown in Fig. $3 \mathrm{a}$ and $b$. The cytoplasm was stained intensely, but the nuclei showed faint reaction. The fluorescence in cytoplasm consisted of fine granules. In the cells at mitotic stage, the entire area of the cells was stained. It was found that all the three sera tested showed staining titers of $1: 64$ (Table II). The titers above were the same as those determined in the in vitro $\mathrm{CF}$ test. However, the 1:16 dilution of them gave more intense fluorescence than that of $1: 64$.

In order to examine reaction of the antiserum against Ehrlich tumor cell to other kinds of ascites tumor cells in mice, experiments with the immunofluores- 

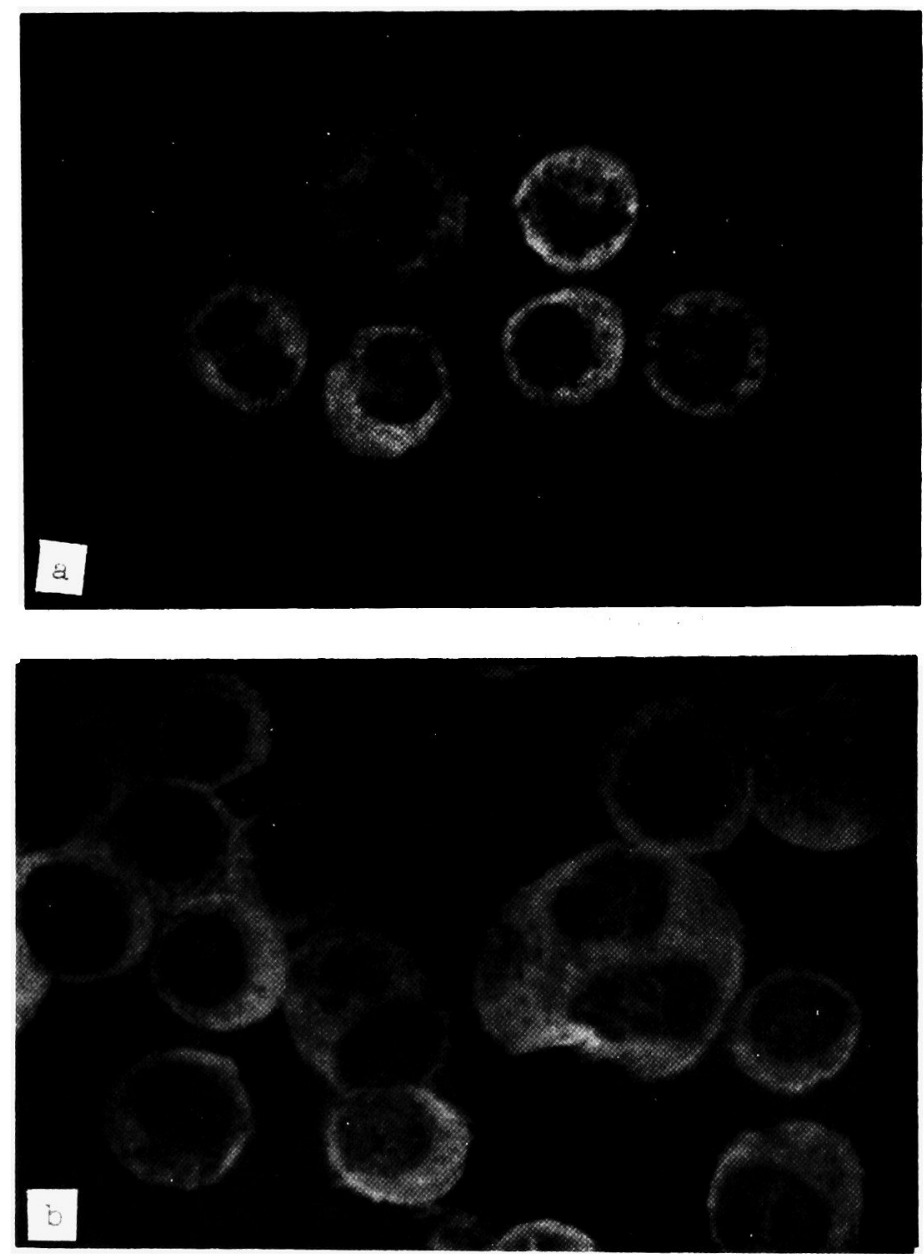

Fig. 3. Ehrlich tumor cells stained by the complement method of immunofluorescence $(\times 400)$.

a. $1: 16$ dilution of No. 11-1 serum was used.

b. $1: 16$ dilution of No. 12-1 serum was used.

cent procedure were performed. The cells of ascites forms of the sarcoma 18011), and of the leukemic ascites tumor SN $36^{12}$ ) were tested. The cells migrated into peritoneal cavity that were produced by intraperitoneal injections of a nutrient broth in normal mice were also examined. Smears of these cells were made on slide glasses by the same procedure in the Ehrlich tumor cells and stained by the complement method using the serum No. 11-1 of 1:16 dilution. Table III summarizes the results. The sarcoma 180 and the leukemic ascites tumor SN 36 were stained as intense as the Ehrlich tumor, but the migrated cells from normal mice were not. This finding suggested a possibility of closs relation of 
TABle II. Staining Titer of Anti-tumor Sera

Determined by the Complement Method of Immunofluorescent Procedure

\begin{tabular}{c|c|c}
\hline Anti-tumor serum no. & $\begin{array}{c}\text { Dilution of the } \\
\text { antiserum }\end{array}$ & $\begin{array}{c}\text { Results of* } \\
\text { staining }\end{array}$ \\
\hline \multirow{3}{*}{$11-1$} & $1: 4$ & 4 \\
$1: 16$ & 4 \\
$1: 64$ & 2 \\
$1: 256$ & \pm \\
\hline \multirow{3}{*}{$12-1$} & $1: 4$ & 4 \\
& $1: 16$ & 4 \\
$13-1$ & $1: 64$ & \pm \\
\hline & $1: 256$ & 4 \\
& $1: 4$ & 4 \\
1 & $1: 16$ & 2 \\
& $1: 256$ &
\end{tabular}

* Intensity of staining: from 0 to 4 .

TABLE III. Immunofluorescent Staining of Tumor and Non-tumor Cells by the Anti-Ehrlich Tumor Serum, No. $11-1^{\text {a }}$

\begin{tabular}{c|c}
\hline Cells smear & $\begin{array}{c}\text { Results of } \\
\text { stainingb }\end{array}$ \\
\hline $\begin{array}{c}\text { Ehrlich ascites tumor } \\
\text { cells }\end{array}$ & 4 \\
$\begin{array}{c}\text { Crocker's sarcoma 180 } \\
\text { (ascites form) }\end{array}$ & 2 \\
$\begin{array}{c}\text { Leukemic ascites tumor } \\
\text { SN 36 }\end{array}$ & 2 \\
Normal cells & 0
\end{tabular}

a. $1: 16$ dilution of the antiserum was used for staining.

b. Intensity of staining: from 0 to 4 .

the Ehrlich tumor antigen to the antigens of sarcoma 180 and leukemic ascites tumor SN 36, but not to the antigen of non-tumor cells from normal mice.

\section{DISCUSSION}

In CF tests, rabbit antiserum against the FC treated Ehrlich tumor antigen showed high titer of antibody with the homologous antigen, but no or only a slight reaction with the host muscle antigen. The antiserum stained the tumor cells but not the non-tumor cell of mouse in immunofluorescent procedure. On the other hand, rabbit antiserum against the $\mathrm{FC}$ treated muscle antigen reacted 
to the homologous antigen but not to the FC treated tumor antigen. These results suggest that the FC treatment is effective for purification of the Ehrlich tumor cell antigen which was not common to the muscle tissue and the non-tumor peritoneal cells of the host. A specificity of the antibody against the tumor antigen was more clearly shown in the antisera obtained in early stage of immunization than in the latter stage. However, it was also true that an antibody (or antibodies) against the host muscle was produced in the serum after hyper-immunization with the FC treated tumor antigen, although the titer was much lower than that of homologous antibody. This suggests that the FC treated tumor antigen contained a little amount of the common antigen shared by the muscle. It was interesting that in vitro CF titer of the anti-tumor serum roughly corresponded to the staining titer of the complement method of immunofluorescence as in a case of viral antigens $\left.{ }^{9}, 10\right)$. In the present studies, the reactivity of the anti-tumor serum prepared by the immunization with the purified tumor antigen to various kinds of mouse tissues was not examined. Therefore, conclusive answer on the effect of FC treatment on purification of the tumor specific antigen should await further studies. However, it was interesting that the antibody against the Ehrlich ascites tumor cells stained the other kinds of tumor cells, the sarcoma 180 and the $\mathrm{SN} 36$ by immunofluorescence, suggesting that antigens of these tumor cells were closely related each other.

\section{Acknowledgment}

Most of this work was done in the Department of Bacteriology, Tohoku University School of Medicine under the direction of Prof. N. Ishida and Assoc. Prof. Y. Hinuma.

The author wishes to express his thanks to Prof. K. Oh-Uti, Prof. N. Ishida and Assoc. Prof. Y. Hinuma for cordial guidance throughout this work.

\section{References}

1) Gessler, A.E., Bender, C.E. \& Parkinson, M.C., Trans. N.Y. Acad. Sci., 1956, 18, 701.

2) Gessler, A.E., Bender, C.E. \& Parkinson, M.C., ibid., 1956, 18, 707.

3) Hummeler, K. \& Hamparian, V.V., Science, 1957, 125, 547.

4) Hamparian, V.V., Müller, F. \& Hummeler, K., J. Immunol., 1958, 80, 468.

5) Halonen, P., Huebner, R.J. \& Turner, H.C., Proc. Soc. exp. Biol., 1958, 97, 530.

6) Manson, L.A., Rothstein, E.L. \& Rake, G.W., Science, 1957, 125, 546.

7) Taylor, A.R., Gillen, A. \& Brandon, F.B., Virology, 1959, 7, 349.

8) Hummeler, K., J. Immunol., 1957, 79, 337.

9) Hinuma, Y. \& Hummeler, K., ibid., 1961, 87, 367.

10) Hinuma, Y., Ohta, R., Miyamoto, T. \& Ishida, N., ibid., 1963, 89, 19.

11) Goldie, H., Jefferies, B.R., Maxwell, M.C. \& Hahn, P.F., Cancer Res., 1952, 12, 422.

12) Nakamura, K., Gann, 1956, 47, 561. 